\title{
Orlandini's Antigona (vendicata): Transformation of a Venetian Opera on its Transalpine Journey
}

\author{
Jana Spáčilová / jana.spacilova@upol.cz
}

Department of Musicology, Palacký University Olomouc, CZ

\begin{abstract}
The study focuses on the reception of the opera Antigona by Giuseppe Maria Orlandini from its premiere in Venice in 1718 to the productions in Breslau 1728 and Brno 1736. On the basis of newly discovered unique sources (a libretto from 1728 in the Moravian Museum Brno, the score in the Czech Museum of Music Prague, the score of the premiere version in the library of San Francisco State University, reviews in the contemporary press) changes which the work underwent on its way across Europe are presented, and the problem of the aesthetic categories of the pasticcio, in the context of Transalpine production of Italian opera seria, is restored.
\end{abstract}

\section{Keywords}

Opera, Venice, Wrocław (Breslau), Brno, libretto, score, pasticcio, Antigona, Giuseppe Maria Orlandini 
Thanks to travelling opera companies, the Italian opera seria began to penetrate beyond the Alps in the 1720 s, which brought a new impulse into the development of this genre. ${ }^{1}$ It became particularly popular in many parts of Central Europe. The systematic tradition of operas open to the public was launched in Prague in 1724 by Antonio Denzio's opera company. ${ }^{2}$ A spin-off of the Prague company opened in Breslau (Wrocław) in the spring of 1725, making the Silesian city the second hub of Italian opera in the Czech Lands. ${ }^{3}$ It would be incorrect, however, to argue that Breslau was merely "the operatic colony of Prague" ${ }^{4}$ because both the repertoire and performers travelled in both directions (see Table 1).

In 1728 the Carinthian Gate Theatre (Kärntnertortheater) began holding public opera performances in Vienna. The theatre soon became the leading transalpine centre of Italian opera, producing as many as 13 premieres a year. The genre enjoyed great success in Moravia in the 1730s. In addition to the Italian company of Angelo Mingotti performing in the Brno city theatre "della Taverna", the Moravian castles of Jaroměřice, Kroměříž, Vyškov and Holešov held private opera productions. The main patrons of the opera in Moravia were Count Johann Adam of Questenberg ${ }^{5}$ and Wolfgang Hannibal Schrattenbach, Bishop of Olomouc and former Regent of Naples. ${ }^{6}$ The above-mentioned Central European opera hubs were closely linked, as many Italian artists moved from one venue to another. ${ }^{7}$

The primary source of information about the repertoires of the venues is the surviving librettos. In the case of the Silesian city of Breslau, we not only have the remaining librettos at our disposal, ${ }^{8}$ but also the period list of the repertory, included in the biography of Daniel Gottlieb Treu in Mattheson's Grundlage einer Ehrenpforte. ${ }^{9}$ The text

1 The present study further develops the thematic topics defined in a paper presented at the 17 th Biennial International Conference on Baroque Music in Canterbury (July 2016). The completion of the study was made possible thanks to the grant project GA16-17615S.

2 FREEMAN, Daniel E. The Opera Theater of Count Franz Anton von Sporck in Prague. Studies in Czech Music 2, Stuyvesant - New York: Pendragon Press, 1992.

3 BORCHERDT, Hans Heinrich. Geschichte der italienischen Oper in Breslau. Zeitschrift des Vereins für Geschichte Schlesiens, 1910, vol. 44, pp. 18-51; SPÁČILOVÁ, Jana. Počátky opery ve Slezsku - současný stav pramenů [The Origins of the Opera in Silesia - the Current State of Sources]. Musicologica Brunensia, 2016, vol. 51, no. 2, pp. 157-170.

4 FREEMAN, Daniel E. The Opera Theater of Count Franz Anton von Sporck in Prague, op. cit., p. 74.

5 PERUTKOVÁ, Jana. Der glorreiche Nahmen Adami. Johann Adam Graf von Questenberg (1678-1752) als Förderer der italienischen Oper in Mähren. Wien: Hollitzer, 2015.

6 SPÁČILOVÁ, Jana. Die Rezeption der italienischen Oper am Hofe des Olmützer Bischofs Schrattenbach. In MACEK, Petr - PERUTKOVÁ, Jana (edd.). The Eighteenth-Century Italian Opera Seria. Metamorphoses of the Opera in the Imperial Age. Praha: KLP, 2013, pp. 75-88.

7 SPÁČILOVÁ, Jana. Soloists of the Opera Productions in Brno, Holešov, Kroměříž and Vyškov. Italian Opera Singers in Moravian Sources c. 1720-1740 (Part I). In ZUR NIEDEN, Gesa - OVER, Berthold (edd.). Musicians' Mobilities and Music Migrations in Early Modern Europe. Biographical Patterns and Cultural Exchanges, Mainz: Transcript-Verlag, 2016, pp. 255-273.

8 List of Breslau librettos in SPÁČILOVÁ, Jana. Počátky opery ve Slezsku - současný stav pramenů, op. cit.

9 Verzeichnis aller welschen Opern, welche von 1725 bis 1734 auf dem breslauischen Schauplatz vorgestellet worden sind. In MATTHESON, Johann. Grundlage einer Ehrenpforte, Hamburg, 1740, pp. 374-378. 
is entitled Verzeichnis aller welschen Opern, welche von 1725 bis 1734 auf dem breslauischen Schauplatz vorgestellet worden sind and was written by Johann Georg Hoffmann, a local organist, who played second harpsichord in the company; his personal testimony is therefore immensely valuable. Hoffmann not only mentioned the titles of the operas, but also the names of the authors of both the music and the librettos, the names of the members of the company and, in a few cases, also the voice characteristics of the soloists.

The list of operas performed in Prague is available in a monograph by Freeman, while the repertoire of the Viennese Kärntnertortheater is currently researched under the ÖEAW project led by Andrea Sommer-Mathis. ${ }^{10}$ The Moravian librettos have been the subject of my research over the last few years; a catalogue of them is scheduled to be published by the end of 2019 .

Documents related to the music itself are much sparser. This is due to the fact that librettos used to be published in hundreds of copies and were often kept as keepsakes of opera performances, while the manuscript scores and parts were performing material, which lost their purpose after use. The music collection of over 40 scores from Jaroměřice, recently identified by Jana Perutková, is an absolute exception; ${ }^{11}$ only a few items survived from the other Central European centres of Italian opera. ${ }^{12}$

Each and every source, that can add information about the spread of Italian opera beyond the Alps, is therefore very important. This is the case of the libretto and score of Orlandini's Antigona vendicata, performed in Breslau in 1728, which were recently found in Czech musical institutions. A comparison with other sources revealed that this item is a truly interesting testimony to the treatment of an Italian opera in Central Europe, and may reopen the question of the authenticity of the aesthetic perception of opera pasticcio in the eighteenth century.

Orlandini's Antigona to a libretto by Benedetto Pasqualigo premiered in Venice at the Teatro S. Cassiano in 1718. ${ }^{13}$ Giuseppe Maria Orlandini (1676-1760), the maestro di cappella to the Duke of Tuscany, ranked in his day among the most influential authors of Venetian opera, and his name is actually enciphered (besides Vivaldi and Porta) in the title page of Marcello's satirical treatise Il teatro alla moda. ${ }^{14}$ Antigona was one of Orlandini's most successful operas, as is also evident from the fact that Venice saw it

10 SOMMER-MATHIS, Andrea. Die Anfänge des Wiener Kärntnertortheaters zwischen deutschprächiger Stegreifkomödie und italienischer Oper. Divadelni revue, 2015, vol. 26, pp. 139-152.

11 PERUTKOVÁ, Jana. Der glorreiche Nahmen Adami. Johann Adam Graf von Questenberg (1678-1752) als Förderer der italienischen Oper in Mähren, op. cit., pp. 91-94.

12 Issipile and Andromaca by Antonio Bioni are two operas known from Breslau (see ČERNÁ, Zuzana. Antonio Bioni and His Compositions Preserved in Kroměříž Archive, Musicologica Brunensia, 2017, vol. 52, no. 2, pp. 217-242.); to identify part of Vivaldi’s opera Argippo see MACEK, Ondřej. Vivaldi’s Prague Opera Argippo and its Reconstruction, In MACEK, Petr - PERUTKOVÁ, Jana (edd.). The Eighteenth-Century Italian Opera Seria. Metamorphoses of the Opera in the Imperial Age. Praha: KLP, 2013, pp. 89-98.

13 Antigona. Tragedia da cantarsi nel Teatro Tron nel carnovale dell'anno 1718. Offerita a G. A. G. da Merindo Fesanio Past. Arc. Venezia: Marino Rossetti, 1718. Libretto I-Mb Racc.dramm.2267. Cf. SELFRIDGE-FIELD, Eleanor. A New Chronology of Venetian Opera and Related Genres, 1660-1760, Stanford: Stanford University Press, 2007, pp. 340-341.

14 „Si vende nella strada del corallo alla porta del palazzo d'Orlando.“ 
four times a few years apart. The second staging of Orlandini's opera took place at the 1721 carnival at the Teatro S. Angelo, ${ }^{15}$ and the third in the autumn of 1724, again at the Teatro S. Cassiano. ${ }^{16}$ The piece was made into a spoken play, performed as Antigona in Tebe in Venice's Teatro S. Samuele, in $1722 .{ }^{17}$ For the purposes of a play, the libretto was rewritten, and the original five acts were made into three, but the distribution of scenes was preserved. The play was extended by a musical prologue and intermezzo. ${ }^{18}$

The carnival in 1723 sees the performance of the opera in Pesaro as adapted by Agostino Tinazzolli. ${ }^{19}$ Another two versions of the opera were presented in 1727 . For the Torino carnival production, Orlandini changed most of the arias "for various reasons", as indicated in the printed libretto. ${ }^{20}$ Substantial alterations were made for the Bologna summer production. The opera was renamed La fedeltà coronata, and the libretto now had three instead of five acts (the division differed, however, from the 1722 spoken play). ${ }^{21}$ The piece was significantly changed, especially the second and third acts; only five remained in place out of the original musical numbers. ${ }^{22}$

Antigona soon found its way beyond the Alps, conquering the Brunswick stage as early as $1724 .{ }^{23}$ Here it was also divided into three acts, with the musical numbers literally copying the first version in Venice. The Duke's court housed other two performances of the opera, the first in Wolfenbüttel in 1725 and later in Brunswick in 1732.

Following the Breslau production in 1728, the opera was played by the company of Angelo Mingotti at the 1736 carnival in Brno. ${ }^{24}$ The title was changed to Antigona in Tebe, but the name Die gerochene Antigona in a parallel German libretto indicates that the

15 Antigona. Tragedia ristretta ad uso di cantarsi la seconda volta nel Teatro di S. Angelo il carnevale dell'anno 1721. Di Merindo Fesanio Past. Arc. Venezia: Marino Rossetti, 1721. Libretto I-Mb Racc.dramm.815.

16 Antigona. Tragedia di Merindo Fesanio Past. Arc. ristretta ad uso di riccantarsi nel Teatro Trono in S. Cassano. L'autunno dell'anno 1734. Quarta Veneta impressione. Venezia: Marino Rossetti, [1724]. Libretto I-Mb Racc.dramm.814.

17 Antigona in Tebe. Opera tragica tradotta dal drama musicale. Da recitarsi nel teatro Grimani di S. Samuele [...] Venezia: Antonio Gislon, 1722. Libretto I-Mb Racc.dramm.2296.

18 Prologo et intermedio da recitarsi in musica nell'opera dell'Antigona. Nel teatro Grimani in S. Samuele nell'anno 1722. Venezia: Antonio Gislon, 1722. Libretto I-Mb Racc.dramm.3665.

19 Antigona. Dramma per musica da rappresentarsi nel pubblico teatro di Pesaro il carnevale 1723. Pesaro: Gavelli, 1722 [dedication dated 18 Dec. 1722]. Libretto I-Bc 3570, fol. [4r]: „La musica è del sig. Giuseppe Maria Orlandini maestro di capella del sereniss. gran principe di Toscana. Con aggiunte, e mutazione d'arie del sig. Agostino Tinazzoli direttore dell'opera."

20 Antigona. Tragedia per musica da rappresentarsi nel Regio Teatro di Torino, il carnevale dell'anno 1727. Dedicato all'altezza reale di Polisena d'Hassia Rheinsfeld Rottemburgo principessa di Piemonte etc. Torino: Francesco Antonio Gattinara, [1727]. Libretto I-Bc 3572, fol. [3r]: „,ho variate l'altre [arie] per diversi motivi [...]“. 21 La fedeltà coronata. Drama per musica da rappresentarsi in Bologna nel Teatro Malvezzi la state dell'anno 1727. Bologna: Clemente Maria Sassi, 1727. Libretto I-Bc 3593.

22 Or che al ciel Giocasta e cara (Evalco, I/5), A un balen del ciglio amato (Giocasta, I/8), Al fulgor d'amica stella (Osmene, I/10), O sul soglio, o ai vostri altari (Antigona, II/2), Fiumicel, che scarsa ha l'onda (Evalco, III/2).

23 Antigona. Drama per musica da rappresentarsi sul famosissimo Teatro di Braunsviga nella fiera d'estate l'anno 1724. Wolfenbüttel: Christian Bartsch, [1724]. Libretto D-W Textb. 373.

24 Antigona in Tebe. Dramma per musica da rappresentarsi in Bruna nel novo Teatro della Taverna consecrato a [...] Giovanni Adamo [...] di Questenberg [...] nel'carnovale dell'anno 1736. Bruna: Giacomo Massimiliano Swoboda, 1736. Libretto CZ-KRaZ/a XII 45, adl. 2, lost, quoted in SEHNAL, Jiří. Hudebni literatura zá- 
opera had arrived here from Breslau. The performance was dedicated to Count Johann Adam of Questenberg. As this major Moravian musical patron was close to Silesia, he often had librettos and musical instruments sent over from Breslau. ${ }^{25} \mathrm{It}$ is therefore possible that he himself procured the opera. Other possibilities, however, are also conceivable, for example, thanks to one of the solo singers Giuseppe Nicola Alberti, who appeared in both the productions (see Table 2). The relationship between the two versions cannot be clarified in detail as the Brno libretto was sadly lost. The last production of Orlandini's opera that we know of, was held in Vienna in 1741, again in an altered form with several new arias. ${ }^{26}$

Until recently, only one music source of Orlandini's Antigona was usually mentioned: a score stored in the British Library. ${ }^{27}$ The source, however, did not belong to the Venice 1718 version, as is often alleged; it is Orlandini's second version La fedeltà coronata. This is evident both from the analysis of the text (the opera has three acts, and the arias match the Bologna 1727 libretto) and the vocal cast inscribed on the title page. ${ }^{28}$

The other source is described by Eleanor Selfridge-Field in her New Chronology of Venetian Opera. ${ }^{29}$ It is a score now stored in San Francisco, including arias from Antigona, mostly entitled with the name of the composer and with "San Cassiano terza" (order of operas in Venice carnival staggiona). Musical numbers are not written continuously, but each in a separate folder; the order was jumbled during the binding (see Table 3). It is complete music to the opera excluding the recitatives and choirs, not just "nearly all arias", as stated in the RISM catalogue entry to this source. Two proofs confirm that it is the score to the first production in Venice in 1718. The first is the aria Stelle oscure io non v'intendo, replaced in all the subsequent versions. Secondly, the source includes the ballet parts, while the ballets were substituted by intermezzos in the second and third Venice productions. ${ }^{30}$

mecké knihovny v Kroměř́ži [Music Literature in the Castle Library in Kroměříž], Gottwaldov: Oblastní museum a galerie, 1960, no. 11, p. 29.

25 Cf. PERUTKOVÁ, Jana. Der glorreiche Nahmen Adami. Johann Adam Graf von Questenberg (1678-1752) als Förderer der italienischen Oper in Mähren, op. cit., pp. 207-208.

26 Antigona. Opera musicale nel Teatro Privilegiato da S. M. Reale. In Vienna nell'anno 1741. Vienna: Pietro van Ghelen, [1741]. Libretto A-Wn 444501-A. The opera consists of three acts, with thirteen arias being reproductions of the 1718 version, while eight are newly inserted (among them Almen, se non poss'io and Passagier, che su la sponda from Metastasio's librettos La clemenza di Tito and Semiramide riconosciuta).

27 L’Antigona. Del Sig:r Giuseppe M:a Orlandini. Score GB-Lbl Add. 16066, RISM ID no.: 806435686.

28 Creonte - Sig:r Cavagliere Nicola Grimaldi, Osmene - Sig:r Antonio Bernacchi, Giocasta - Sig:ra Teresa Cotti; Antigona - Sig:ra Antonia Merighi; Ceraste - Sig:r Carlo Broschi; Evalco - Sig:r Gian-battista Minelli; Ormindo - Sig:r Francesco Costanzi. Cf. Table 2.

29 SELFRIDGE-FIELD, Eleanor. A New Chronology of Venetian Opera and Related Genres, 1660-1760, op. cit., pp. 340-341. Score US-SFsc *M2.5 v. 66, RISM ID no.: 000119289. I want to express my gratitude to Martin Liebl for providing me with the copy of the score.

30 According to a letter by Eleanore Selfridge-Fields from 3 November 2017, the ballet music was not composed by Orlandini. I would hereby like to express my thanks to her for having offered her advice and counselling regarding this issue. 
Let us now look more closely at the newly found sources complementing Mattheson's information about the 1728 Breslau production of Orlandini's Antigona. ${ }^{31}$ A libretto entitled Antigona vendicata is stored at the Department of the History of Music, Brno Moravian Museum (see Fig 1). ${ }^{32}$

The title page:

ANTIGONA | VENDICATA. | TRAGEDIA PER MUSICA. | Da Rappresentarsi nel Teatro di Breslauia | Nel Ottobre dell' ANNO 1728. | CONSACRATO | ALL' | ILLUSTRISSIMO SIGNORE | ALBERTO | CHRISTOFFORO | Burggrauio e Conte di | DOHNA, | Cavaliere dell' Ord. di S. Giouanni | in Gierusalemme; | etc. etc.

German version on facing page:

Die gerochene | ANTIGONA. | Sing- und Trauer-Spiel, | Welches auf dem THEATRO zu Breslau | in dem Wein-Monath des 1728 Jahres vorgestellet; | Und | Dem Hoch- und Wohlgebohrnen | HERRN, | Herrn Albrecht Christoph, | Des Heil. Röm. Reichs Burggrafen, | und Grafen zu | DOHNA; | Freyen Standes-Herrn in Schlesien, | Zu Wartenberg, Bralin, Herrn auf Globitten und Klein-|Heyde, auch auf Glodien, Carwinden und Reichs-|walde Erb-Herrn; | Des Johannitter-Ordens Rittern; etc. etc. | unterthänigst dediciret wird.

The libretto was dedicated to Count Albrecht Christoph Dohna-Schlobitten (1698-1752), the owner of the mansion Wartenberg, located not far from Breslau (today Syców). The undated dedication is signed by the impresario Santo Burigotti. According to the book plate, the copy of the libretto originated from the library of Count Ignaz Dominik Chorinsky, a prominent Silesian music patron of the second half of the eighteenth century.

This libretto was definitely connected with an anonymous score entitled Opera del'Antigona, which comes from the music collection of Chotek's Castle of Kačina and is now stored in the Czech Museum of Music in Prague (see Fig 2, 3). ${ }^{33}$ The score came to the collection before the beginning of the 19th century because it is recorded in one of the Kačina inventories (see Fig. 4). ${ }^{34}$ The score is transcribed by one copyist

31 Verzeichnis aller welschen Opern, welche von 1725 bis 1734 auf dem breslauischen Schauplatz vorgestellet worden sind, op. cit., p. 376: „Antigone [!] vendicata, Tragedia per Musica, im October, von signore Gioseppe Maria Orlandini in die Musik gebracht."

32 Cz-Bm B 373, 61 fol. in quarto [5 fol. + A1-O4], text Italian-German on facing pages, dust cover: brownblack spotted paper. 1v: title page it., 2r: title page ger., 2v: Illustrissimo Signore! [...] Santo Burigotti, 3r: Hochund Wohlgebohrner Burggraf und Graf, 3v: Argomento, 4r: Inhalt, 4v: Mutazioni di scene, 5r: Veränderungen derer Scenen, 5v: Personaggi, 6r [A1r]: Vorstellende Personen, 6v [A1v]: Atto primo.

33 Cz-Pnm XLI D 1, stará sign. Kl. IV. 824. A one-volume score, 305x235 mm, 76 fol., bound in red-blueyellow marbled oil paper, corners in brown skin decorated with three carvings. Spine: seven bindings, ink $\mathrm{n}$. LII on the spine, labels with old signatures on the cover: "Kl. IV, 824“, „28“, „49“. A mint of the Chotek coat of arms in the centre of the cover. Title page (fol. 1r): "Opera | del'Antigona".

34 Catalog der Oper, Oratorien und einzelnen Singstücken, CZ-Pnm, př́r. č. 95/65,2, Nr. 49 in the category "Arien". For more information about Kačina inventories, see FUKAČ, Jiří. Dochované inventáře chotkovské hudební sbírky na zámku Kačina. K vydání připravili Jiří K. Kroupa a Jana Spáčilová. Antiqua Cuthna 5-11, Praha 2015, s. 42-64. 
hand on a single type of paper with a "shamrock" watermark (see Fig 5). The Breslau provenance was confirmed through a copyist analysis. ${ }^{35}$ The source contains complete musical numbers of the Breslau libretto, with one exception - Evalco's aria Fiumicel, che scarsa l'onda. The arias are entered in the wrong order. The distribution of the copyist folders nonetheless indicates that they were not copied separately but altogether, and their order must have been jumbled already in the original. ${ }^{36}$ There is one page with the bass part, identified as the first movement of sinfonia (fol. 76r), in the final part of the score. Numerous errors in the Italian text suggest hasty copying. Errors also occur in the organisation of the acts: the title "Atto seconda" [!] is inserted between the first and the second aria of the second act (fol. 18r), "Atto terzo" is then put before the closing aria of the third act (fol. 35r), and the latter is followed with the inscription "Fine" which should only be placed after coro finale (fol. $37 \mathrm{v}){ }^{37}$

The newly discovered sources reveal the form in which Orlandini's Antigona was produced in Breslau. The opera was divided into three acts, like in Brunswick and Bologna, but no other affinity with either of the two versions can be established. Out of all the previous versions it is closest to the Venice 1724 version. This can be clearly determined from the aria Del mio amor l'auree catene, which appears only in this one version, and also from the end of Scene 7, Act 3 (corresponds to Venetian V/1). In terms of the layout of scenes and arias, the Breslau opera follows the 1724 version, with the exception of the moving Antigona's aria Poiche il dorso al mar flagella from Scene 6 to 12 of Act 1 (in Venice it corresponds to Scene II/6).

As the score of the 1724 Venetian production has not been preserved, only the relationship to the 1718 premiere version has been subject to analysis. Likewise, the analysis only focuses on the arias because the recitative parts have not been preserved in either of the relevant sources. A comparative view of the Breslau score with the premiere score stored in San Francisco reveals a recurrence of two types of changes: transpositions and substitutions of arias (see Table 4). Amendments within the arias occur exceptionally, this in the form of a number of deletions and one inserted ritornello. All of these amount to changes in the musical structure and suggest no simplification of the singing parts. $^{38}$

Part of these changes naturally result from alterations in the cast of the singers (see Table 2). The role of Antigona was performed by Chiara Orlandi, a member of the

35 Cf. PERUTKOVÁ, Jana. Der glorreiche Nahmen Adami. Johann Adam Graf von Questenberg (1678-1752) als Förderer der italienischen Oper in Mähren, op. cit., pp. 52-53.

36 Folders and number of folios: 1) fol. 1-8 [fol. 1r title page], 2) fol. 9-16, 3) fol. 17-26, 4) fol. 27-34, 5) fol. 35-37 [last folio of the folder cut out], 6) fol. 38-45 [fol. 38r vacant], 7) fol. 46-53, 8) fol. 54-61, 9) fol. 62-69, 10) fol. 70-76 [last folio of the folder cut out, fol. 76v vacant]. For the organisation of the arias at the individual folders, see Table 4.

37 This may suggest that the copy was only made on the basis of individual arias and not the opera as a whole.

38 In the aria Tace il labro, e parla il ciglio, a ten-bars ritornello is inserted before the A section, this probably due to the fact that the aria begins directly with solo singing. In the aria $O$ sul soglio, o a vostri altari, the last 7 bars are missing. This also seems to be an error as it makes the B section's closing illogical in terms of the music. Deletions occur within arias Pensa al regno (11 bars), Versero dagli occhi il pianto (3 bars) and Fremi pur, pensa, e consiglia (16 bars). 
Breslau company since its very foundation in $1725 .{ }^{39}$ Mattheson called her "eine Altistin", his judgement is confirmed by the definition of the voice register in the Breslau score. ${ }^{40}$ Three of her arias have remained unchanged (I/8, I/12, II/2), two were then transposed down by one second (II/10, III/6).

The role of the tyrant Creonte was sang by the tenor Giuseppe Nicola Alberti, himself a member of the Breslau company since 1725. Later he performed with Orlandi at other places around Central Europe. ${ }^{41}$ Apart from his career as a singer, he was also devoted to composing. The only new aria added for his role, Pur ch'io salvi e vita, e regno, is written in bass cleff. With a voice range defined as $\mathrm{B}-\mathrm{f}^{1}$ it is not very different, however, from the rest of the role (one of the original arias Fu di re comando allora is defined as $\mathrm{B}-\mathrm{g}^{1}$ ).

Similarly, the role of Giocasta is based on Orlandini's original: out of four arias, three are transposed and one substituted altogether. The transposition down by a fourth (fifth respectively) followed the need to amend the original soprano role for alto singer Barbara Bianchi. ${ }^{42}$ The header in the score "Del Sigr. Finazzi" generously reveals the name of the author of the new aria (see Fig 6). ${ }^{43}$

A soprano-castrato Filippo Finazzi came to Breslau shortly before the staging of Antigona, which meant a debut appearance for him at the local stage. ${ }^{44}$ His role as Giocasta's

39 She performed mostly in Venice from 1717, her roles worth mentioning include Ceraste in Orlandini's Antigona in 1721 at Teatro S. Angelo. She was recommended to Denzio by Antonio Vivaldi in 1725, yet her transalpine career did not begin in Prague but in Breslau where she moved accompanied by her husband, the choreographer Gaetano Orlandi. Prague first saw her perform in the season 1727/28 after which the couple returned to Breslau and later to Venice. She later also performed in Brno, Holešov and Graz.

40 Verzeichnis aller welschen Opern, welche von 1725 bis 1734 auf dem breslauischen Schauplatz vorgestellet worden sind, op. cit., p. 374. At the time when she was performing in Italy, she was considered a soprano which is why Denzio calls her "Chiara Orlandi Soprana" in his letter to Johann Wenzel Czernin (cf. FREEMAN, Daniel E. The Opera Theater of Count Franz Anton von Sporck in Prague, op. cit., p. 289). Considering the roles written for her by Antonio Vivaldi (Erminia in Armida al campo d'Egitto, RV 699, and Rustena in La verità in cimento, RV 739), her voice can be characterised as a mezzo-soprano.

41 According to Verzeichnis aller welschen Opern, welche von 1725 bis 1734 auf dem breslauischen Schauplatz vorgestellet worden sind, op. cit., p. 374, Alberti was "ein Tenorist, insonderheit zu lustigen und flüchtigen Sachen aufgelegt." Alberti stayed in Breslau up until 1729, and in the meantime, similar to Orlandi, spent one season in Prague. He took his second transalpine journey in 1733, this time via Ljubljana and Trieste to Brno. He was maestro di capella for Count Franz Anton Rottal in Holešov from 1734-36, his stay was confirmed by librettos and in local parish registers. Cf. SPÁČILOVÁ, Jana. Soloists of the Opera Productions in Brno, Holešov, Kroměříž and Vyškov, op. cit.

42 Barbara Bianchi took the transalpine journey together with her father, the basso Francesco Maria Bianchi. He himself sang in a 1725 opera La fede ne'tradimenti staged at the court of Theodor Constantin Lubomirsky in Kraków (libretto PL-PŁp XVIII.927). In October of the same year, he appeared in Kuks where he died following a short illness (FREEMAN, Daniel E. The Opera Theater of Count Franz Anton von Sporck in Prague, op. cit., p. 303). Barbara Bianchi was a member of Antonio Denzio's company in Prague, after her Breslau experience she performed in Italy and in Ljubljana where she died on 31 January 1733, reportedly at the age of 21 (ŠKERLJ, Stanko. Italijansko gledališče v Ljubljani v preteklih stoletjih. Il teatro italiano a Ljubljana nei secoli passati. Ljubljana: SAZU, 1973, p. 148). According to Verzeichnis aller welschen Opern, welche von 1725 bis 1734 auf dem breslauischen Schauplatz vorgestellet worden sind, op. cit., p. 376, she was "gut im Singen und in der Vorstellung", her talent as a singer was very much acclaimed already during her collaboration with Denzio (FREEMAN, Daniel E. The Opera Theater of Count Franz Anton von Sporck in Prague, op. cit., p. 288).

43 Fol. 41v. The non-correspondence of the text suggests this may be a case of a parody aria.

44 According to Verzeichnis aller welschen Opern, welche von 1725 bis 1734 auf dem breslauischen Schauplatz vorges- 
lover Ceraste was also amended, with only two arias copied from Orlandini's original. The third one, Del mio amor l'auree catene, is only included in the 1724 Venice version for which no music has been preserved. This makes it hard to determine whether it has been copied from this version or inserted newly for Breslau. What is certain is the fact that the aria Per sperar ardo d'amore (transcribed erroneously in the score as Per amar ardo d'amore) was only inserted at the Breslau version.

The performer of Osmene, Giovanni Dreyer, was one of the most remarkable personas of the Breslau company. ${ }^{45}$ The alto-castrato arrived in Silesia in the spring of 1726 and settled there until autumn $1730,{ }^{46}$ which made him one of the most loyal singers in the company. Together with Santo Burigotti, he also worked as the company's impresario in the $1727 / 28$ season, concurrently composing his own works: apart from the intermezzo Vespetta e Velasco $(1728)^{47}$ he also composed the inserted arias in Ariodante (1727) and Merope (1728). ${ }^{48}$ In his role of Antigona's husband was preserved only one aria from Orlandini's original (III/5) Dreyer himself composed the remaining parts, as evident from the inscription "Aria del Sigr. Dreyer" (see Fig 7) printed at his arias in the libretto. With the aria Al fulgor d'amica stella, his authorship is double-confirmed with an extra mark in the score.$^{49}$ For the aria Al padre vanne e di cosi he used a new text, a paraphrase of the original:

\section{Orlandini 1718/1724}

Vanne al padre, a vanne al re; Dilli pur, che sono sposo, Dilli pur, che son fedel.

Padre a me torni amoroso, Non sia al figlio un re crudel.

\section{Dreyer 1728}

Al padre vanne e dì cosi

Che sono amante e sposo

E sposo più fedel

Con il mio ben.

Dille ch'il suo rigor

Sbandisse dal mio cor

Il ben seren.

tellet worden sind, op. cit., p. 376, Filippo Finazzi (1705-1776) was "ein guter Discantcastrat", his arrival in Breslau was very much welcomed by the local press (see further in the text). He stayed in Breslau until the spring of 1730 , active both as a singer and composer. He later in 1760's converted to Protestantism and married on the basis of dispensus.

45 Giovanni Filippo Maria Dreyer (c. 1703-1772), called "il Tedeschino"sang in Italy from 1721. Before Breslau, he spent one season at the Teatro S. Cassiano in Venice, and later performed in Prague and Moscow.

46 Verzeichnis aller welschen Opern, welche von 1725 bis 1734 auf dem breslauischen Schauplatz vorgestellet worden sind, op. cit., p. 375: „Signore Dreyer, ein florentinischer Deutscher und Altcastrate“. Schlesischer Nouvellen-Courier, No. 70, 2. 5. 1726, „...] unter denen neu aus Italien verschriebenen, und zu dieser noch zu der Compagnie trettenden Virtuosen und Virtuosin ist würcklich der Gioanni Treiro ein Castrat, und Contre-Alt angekommen: gleich wie nun solcher auf den berühmtesten Wällschen Theatris grosse Approbation gefunden, und auf denen principalesten gefunden, also ist auch kein Zweifel, daß Er allhier dem gantzen Werck ein grosses Lustre geben werde."

47 Schlesischer Nouvellen-Courier, No. 7, 12. 1. 1728: „Die Music dieser Intermezzi hat der Herr Impressario Gioanni Drayer selbst componiret."

48 Verzeichnis aller welschen Opern, welche von 1725 bis 1734 auf dem breslauischen Schauplatz vorgestellet worden sind, op. cit., p. 376.

49 Fol. 71r „Violoncello Obligato. Del Sigr. Drë̈er.“ 
The two remaining roles have little to do with Orlandini's original. The minor role of Evalco was performed by Chiara Ferri..$^{50}$ Her both preserved arias were composed again by Giovanni Dreyer, as the printed libretto suggests. The second of the two, Dona tempo al gran consiglio, is composed of a new text (Orlandini's original has the aria Se a teso lino alato pino in its place, the 1724 version did not have it at all). ${ }^{51}$ The third aria Fiumicel, che scarsa ha l'onda is recorded in the Breslau libretto, however, it is not included in the score.

The last role, that of the shepherd Ormindo, was performed by the company's impresario Santo Burigotti. ${ }^{52}$ In the Italian versions as well as in the later Brno version, the role was written for a bass voice and it therefore remains unclear why its only aria Nacqui ai boschi, e son pastore is written in the soprano cleff in the Breslau score. If this piece of information is relevant, and as there are no records of any other casting of Burigotti and we know for certain that he was not a castrato, we must assume that he performed the role in falsetto. It is possible, however, that the records in the score are only partly relevant and that the aria was in fact sang by Burigotti in his natural voice register (tenor or bass).

The non-corresponding voice register with this aria and the above-mentioned Creonte's Pur ch'io salvi e vita, e regno suggests that at least some part of the new score may have been borrowed from operas written by other composers: preservation of the cleff can be considered as a result of mechanical transcription. Such an explanation is further supported by the fact that a number of the operas staged in Breslau were explicitly presented as pasticcios; in the libretto of La costanza di Griselda, the names of the respective authors are printed next to the arias they composed.$^{53}$ Unfortunately, the research carried out in the RISM incipit catalogue, with the objective of finding concordances of new arias in the Breslau Antigona, has not produced relevant results. This is largely due to the fact that, with operas from the eighteenth century, the catalogue mainly reflects only sinfonia, opening recitative and the incipit of the first aria.

With the following lines, I will try to characterise different types of changes and suggest the reasons that may have motivated these. The first type of changes, where different voice registers of soloists led to the transposition of existing music or creating of new arias, can be identified as practical. It was conditioned by the personnel capacity of the given opera company and based on the local conditions. In the work subjected to our analysis, it is manifested in the transposition of both female roles and the expansion of Giocasta's role by a new aria $A$ un balen del ciglio amato.

50 Verzeichnis aller welschen Opern, welche von 1725 bis 1734 auf dem breslauischen Schauplatz vorgestellet worden sind, op. cit., p. 376 calls her solely "Chiara Ferri, aus Bononien". Before her Silesian appearances, she sang at Reggio Emilia in 1727. Her life story after leaving Breslau in 1732 remains unknown.

51 The score erroneously reads Dona al tempio il gran consiglio.

52 He worked as impresario in different Italian cities (Torino, Verona, Mantova) from 1721. During his Breslau period he mostly focused on writing librettos. He is explicitely mentioned as the author of Siroe (a libretto adapted from the Metastasio's original) and Ercole su'l Termodonte (only the title is in common with Vivaldi's eponymous work).

53 Libretto La costanza di Griselda is preserved in the private collection of Rainer Theobald in Berlin. 
Additional types of changes was music-related. The reason behind these types of amendments was, above all, respect for the wishes of the soloists. This reason is traditionally considered the most common principal cause for composing pasticcios, with singers insisting on integrating their favourite aria into another opera. The opera in question is a combination of the "dictates of music stars" and the creativity of the local composers. Concerning the role of Osmene, the singer Giovanni Dreyer composed arias for his own voice, while the role of Evalco probably allowed for a greater dramaturgical freedom given that it was a minor role. The composer's respect for Orlandini's original version also manifests itself in the fact that the original key is preserved in all arias (see Table 4).

The fact that music for the two roles was written by another composer is acknowledged in advance in the printed libretto. This process was common at the time in Italian opera: arias written by foreign authors were announced in the libretto headers, further in the text of the libretto they were mostly marked with asterisks ("stelletta").

Apart from the above-mentioned changes, considered rather common and arising from practical or musical reasons, the score includes at least three new arias with no marking of specific authorship: Naqui ai boschi, e son pastore (Ormindo, II/5), Pur ch'io salvi e vita, e regno (Creonte, II/11) and Per sperar ardo d'amore (Ceraste, II/12). We may also count in the above-mentioned aria $A$ un balen del ciglio amato (Giocasta, I/9): if it had been included in the opera during the preparation process, Finazzi's name would have been printed in the libretto (as was the case with Dreyer). All of these arias are newly underlaid with the text from the original libretto, which was not all that common in the period context. Normally, pasticcios consisted of adapted arias including the text, which was possibly slightly paraphrased to fit the new dramatic situation.

The presence of the four newly inserted arias suggests that the Antigona score preserved in Prague, represents the very last version of the opera, which includes the changes that 1) were made while preparing the production and are captured in the printed libretto, and 2) those that were added later during the repeats of the opera. The meticulous adherence to the original texts combined with new music demonstrates the effort to meet the original dramaturgical intention.

This hypothesis can be proved by a historical source that has escaped the attention of scholars dealing with Italian opera in Central Europe (the last to work with the source was Borcherdt). It is Schlesischer Nouvellen-Courier, a bi-weekly published in Breslau as of 1708. The "Home section" typically included news from the local theatre: the periodical provided news about productions, vocal solos, ticket prices and such. It is an excellent picture of the opera of a small German town in the first half of the eighteenth century, and it is only unfortunate that it does not cover the entire time the Italian company spent in Breslau - three whole volumes and some other issues are missing. ${ }^{54}$

The production of Antigona was discussed in the news on several occasions between

54 SCHIERSE, Bruno Bernhard. Das Breslauer Zeitungswesen vor 1742. Breslau: J. U. Kern, 1902, pp. $10-12$. The journal was studied on microfilms borrowed from the Mikrofilmarchiv und Mediathek, Staats- und Universitätbibliothek Bremen. The missing issues lost in Borcherdt's day have not been found. Unlike Schiers, we only found incomplete issues covering 1731-35 and 1738-40 in the Research Library in Olomouc (CZ-OLu 27.004, 27.006). 
late September and early November. The primary attention was given to the newly arrived castrato Finazzi and to new decorations painted by the set designer Pantaleoni. ${ }^{55}$ A report dating back to 4 October mentions a special concert production of the violinist Carlo Zuccari during the opera performance. ${ }^{56}$ At the time Zuccari was in the services of the Olomouc Bishop Wolfgang Hannibal Schrattenbach.

Of fundamental importance is a brief note dated 14 October, which states: "Es wird allen gnädigen Liebhabern und Liebhaberinnen der Music wird gnädigst zu wissen gethan, daß an heuth wieder Veränderungen in denen Arien werden zu hören seyn, umb das Publicum mit der Diversitaet zu bedienen." ${ }^{57}$ Invitations with information about the new aria were announced in several issues of the journal, up until Antigona was finally replaced by another opera Merope. ${ }^{58}$

What does this authentic historical evidence say? Nothing less than instead of practical or musical reasons, the new music was incorporated into the existing opera simply for a change to refresh the audience. This approach to an opera piece, altering some of the music in order to revive the waning audience interest, could be (rather topically) termed commercial. In the above-mentioned journal, many other examples can be found. ${ }^{59}$

This historically authentic perspective of viewing subsequently added music, composed by someone else as enrichment and not a contamination of an opera piece, so-

55 No. 157, 30. 9. 1728: „NB. Man hat nicht ermangeln wollen, dem Publico, absonderlich aber der geneigten Liebhabern, und Liebhaberinnen der Music wissend zu machen, welcher gestalten die neue Compagnie der Opera würckl. auf das Theatre getreten, und sich der neue Virtuoso Filippo Finazzi, den man mit grossen Kosten aus Italien verschieben, zu allgemeiner Begnüg- und Verwunderung hören lassen, mithin man recht sagen kan, daß keine so vollkommene Bande allhier noch nicht gesehen worden, ja in Italien selbst schwer zusammen gebracht werden dürffe: Die jetzige Piece nennet sich Antigona, ein Stück, so in Italien, Schönheit halber, auf alle Theatre oft hat müssen repetiret werden. Die Music ist von dem berühmten Orlandini, von dessen Composition zu Breßlau noch nichts gehöret worden; die Condecorationes des Theatri seynd besonders kunstreich und schön, weiln der Theatralische Mahler Pantaleoni währender Zeit, da keine Opera gehalten worden, Zeit gehabt hat, die Scenen völlig anderst zu mahlen, und ein gantz neues Theatrum vorzustellen. Von der vor-jährigen Bande ist niemand geblieben, als die besten 3 Personagen [= Giovanni Dreyer, Barbara Bianchi, Chiara Ferri], so von den allhiesigen Liebhabern und Liebhaberinnen verlanget werden: man bittet also um einen gnädigen und geneigten Zuspruch."

56 No. 159, 4. 10. 1728: „NB. Es wird allen gnäd. und geneigten Liebhabern und Liebhaberinnen zu wissen gethan, daß der grosse Virtuos in der Geigen, Carlo Zuccarin [!], heut in der Opera etwas von seiner Composition spielen wird: gleichwie nun seines gleichens nicht leicht zu finden, also wird heut eine absonderliche Bewegnüß seyn, die schöne Opera zu sehen, und zahlreich zuzusprechen."

57 No. 165, 14. 10. 1728.

58 No. 167, 18. 10. 1728: „NB. Allen Liebhabern und Liebhaberinnen der Music wird zu wissen gethan, welchergestalt die schöne Opera Antigona heuth vorgestellet wird, so das sehenwürdigste Werth ist, so auf diesem Theatro aufgeführet worden: Man wird in denen Arien verschiedene Veränderungen vornehmen [emphasised by J. S.], wobeynebenst man auch noch erinnern wil, daß sich die Opera puncto um 5 Uhr anfangen wird, mithin man gebeten haben wil, ben Zeiten zu erscheinen. “ No. 169, 21. 10. 1728: „NB. Morgen wird die schöne Opera noch gehalten, wo man sich sodann zu einer neuen wird anschicken müssen: wird demnach um einen gnädigen Zuspruch gebethen.“ No. 173, 28. 10. 1728: „NB. Es wird allen Liebhabern und Liebhaberinnen der Music gehorsamst zur Nachricht gegeben, daß die schöne Opera Antigona, noch heut auf vielfältiges Verlangen produciret wird, dannenhero wil man um eine Zahl-reiche Besuchung gnädigst gebeten haben.“ No. 180, 8. 11.1728: „NB. Es wird allen gnädigen und geneigten Liebhaber- und Liebhaberinnen der Music zu wissen gethan, daß heut die schöne Opera Antigona genannt das allerletzte mahl vorgestellet werde; Weiln man diese Repitition [!] allseitig verlanget hat; mithin glaubet man, wasmassen diese so schöne Piece wohl meritire, daß man zur Beurlaubung noch einmal erscheine: wannenhero dann auch um eine Zahlreiche Besuchung gebethen haben."

Cf. SPÁČILOVÁ, Jana. Počátky opery ve Slezsku - současný stav pramenů, op. cit. 
mewhat undermines the modern concept of the aesthetic category of pasticcio as an inferior opera genre of the eighteenth century. It is essential, however, to realize that this pejorative view stems from the very etymology of the term. "Pasticcio" was first used by Johann Joachim Quantz in his 1755 Lebenslauf as a supposedly authentic designation used in Italy for an opera "jumbled from arias of varied masters". ${ }^{60}$

Quantz's statement, however, reflects his modern aesthetic view and illustrates the changing attitude to the autonomy of a music-dramatic work around the mid-eighteenth century. In the Baroque period, pasticcio was seen as an equal counterpart of the newly created opera, and combining the music of different composers was appreciated for the high variety of taste.$^{61}$ As established by Reinhard Strohm, the salary composers received for pasticcios was the same as for new music, regardless of whether they consisted of portions of their own earlier works ("self-pasticcio") or of other composers ${ }^{62}$ It is no coincidence that a significant share of pasticcios were found among operas by such masters as Antonio Vivaldi and George Frideric Handel - who, in addition to composing, also made a living as opera entrepreneurs and were well aware of the power of success with the audience. ${ }^{63}$

The pasticcio also played an important role in the production of transalpine opera companies for practical reasons, because arias were easier to handle on travels compared with entire files of opera scores. Above all, however, using well-established music from other sources was deemed a guarantee of quality and success. The policy of 'the very best of' is, after all, timeless; it certainly is deserving of attention for helping promote Italian opera around Europe.

Translated by Eva Černínová and Barbora Čermáková.

60 "Hier hörete ich verschiedene Opern, die aber alle von Arien verschiedener Meister zusammen geflicket waren, welche Art von Einrichtung die Welschen eine Pastete, (un pasticcio) zu nennen pflegen”. QUANTZ, Johann Joachim. Herrn Johann Joachim Quantzens Lebenslauf, von ihm selbst entworfen. In MARPURG, Friedrich Wilhelm (ed.). Historisch-Kritische Beyträge zur Aufnahme der Musik, Bd. 1, St. 3, Berlin 1755, p. 230.

61 Verzeichnis aller welschen Opern, welche von 1725 bis 1734 auf dem breslauischen Schauplatz vorgestellet worden sind, p. 376: „Diese Art der Vermischung erhielt anitzo den besten Beyfall und Zugang“ (concerning pasticcio Merope, November 1728).

62 STROHM, Reinhard. Essays on Handel and Italian Opera, op. cit., p. 165

63 Concerning Vivaldi as an opera producer, cf. STROHM, Reinhard. Essays on Handel and Italian Opera, op. cit., p. 122-163. 


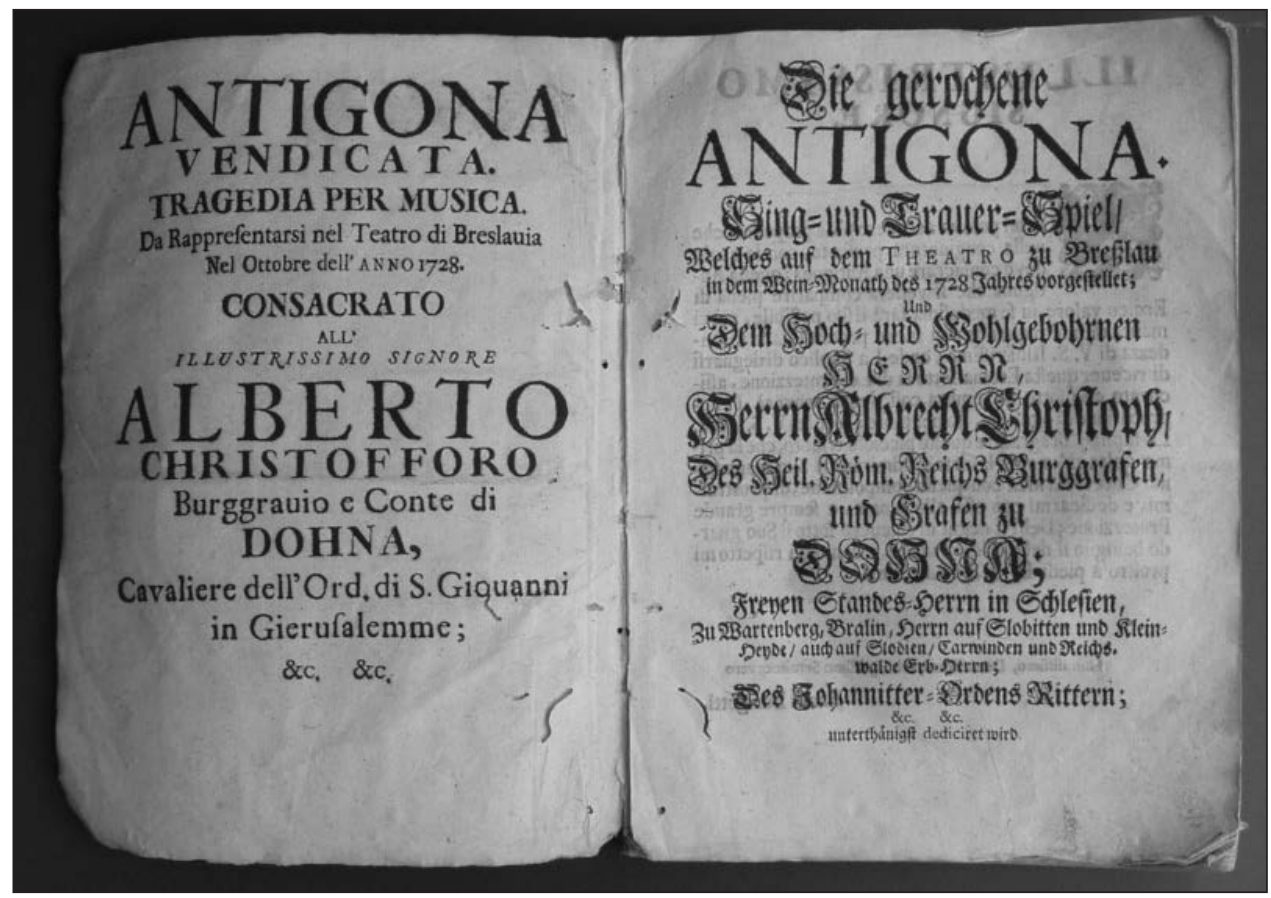

Fig. 1 Title page of the libretto Antigona vendicata, CZ-Bm B 373

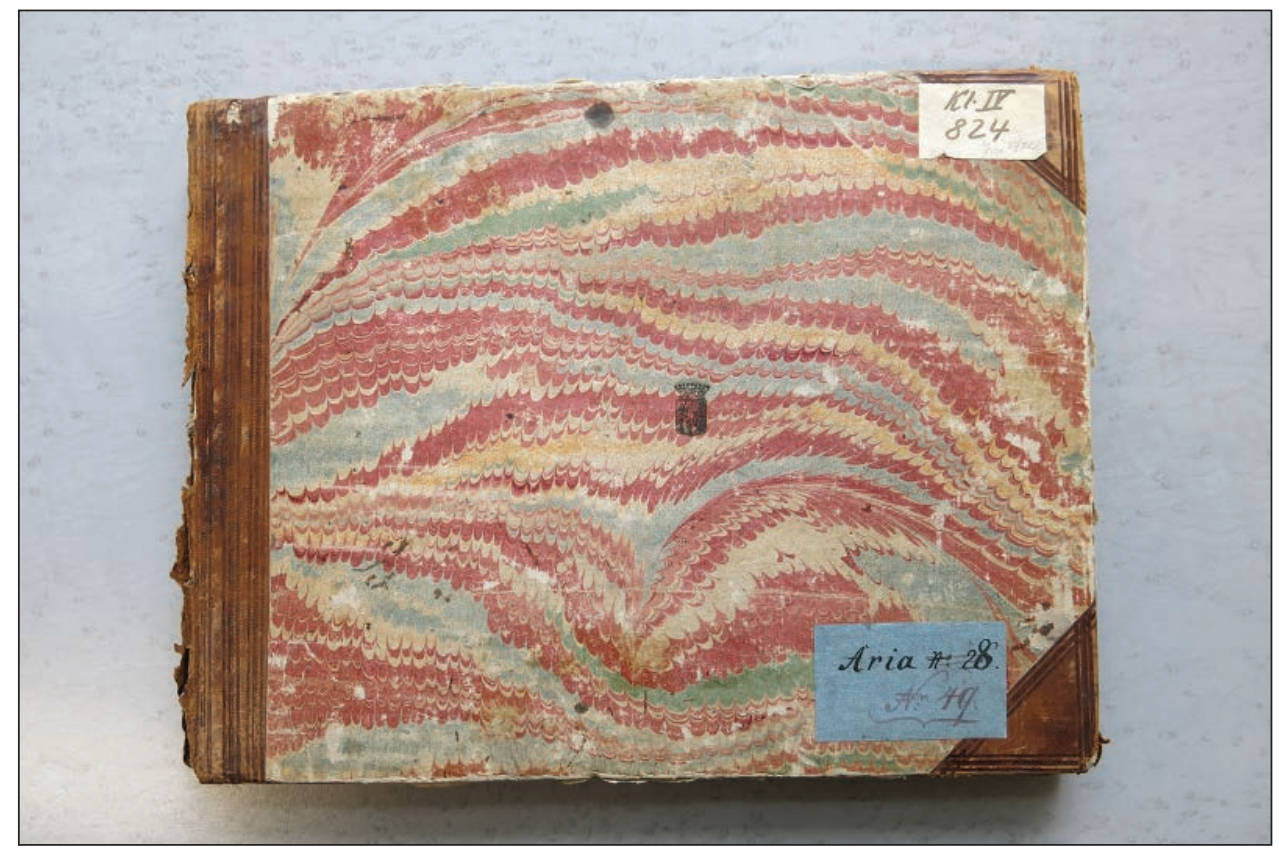

Fig. 2 Anonymous score Opera dell'Antigona, dust cover, CZ-Pnm XLI D 1 


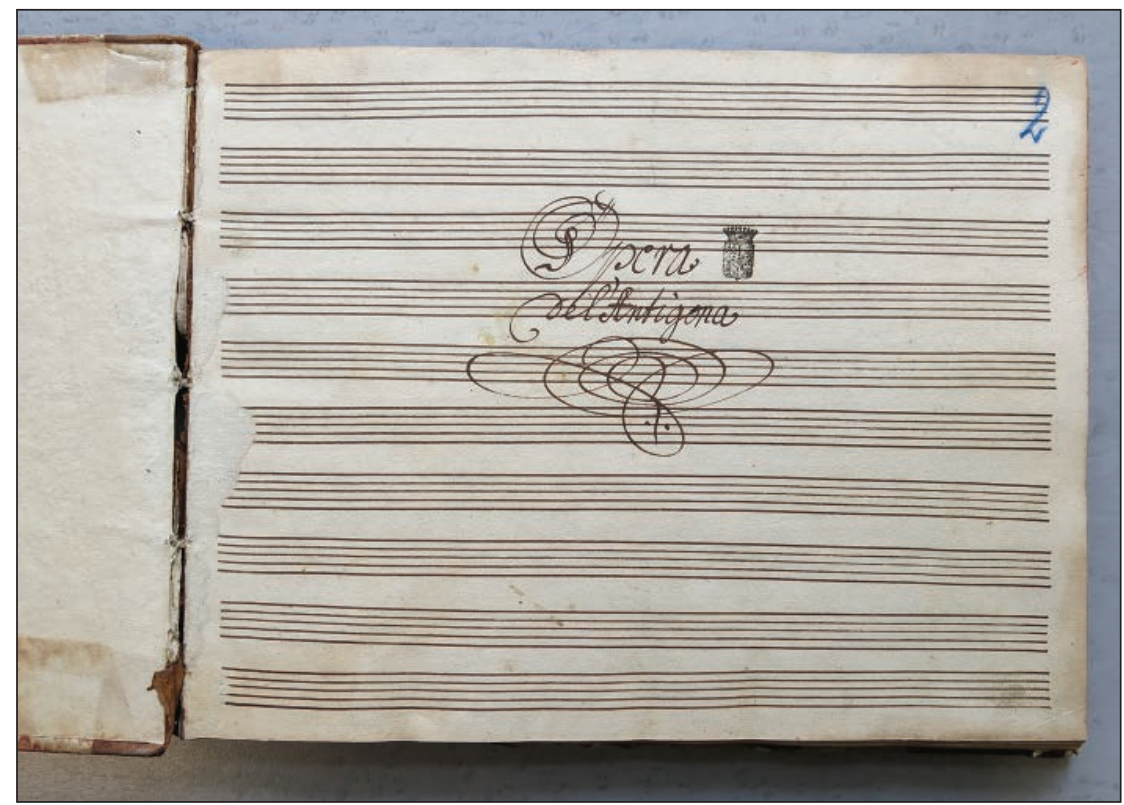

Fig 3. Anonymous score Opera dell'Antigona, title page, CZ-Pnm XLI D 1

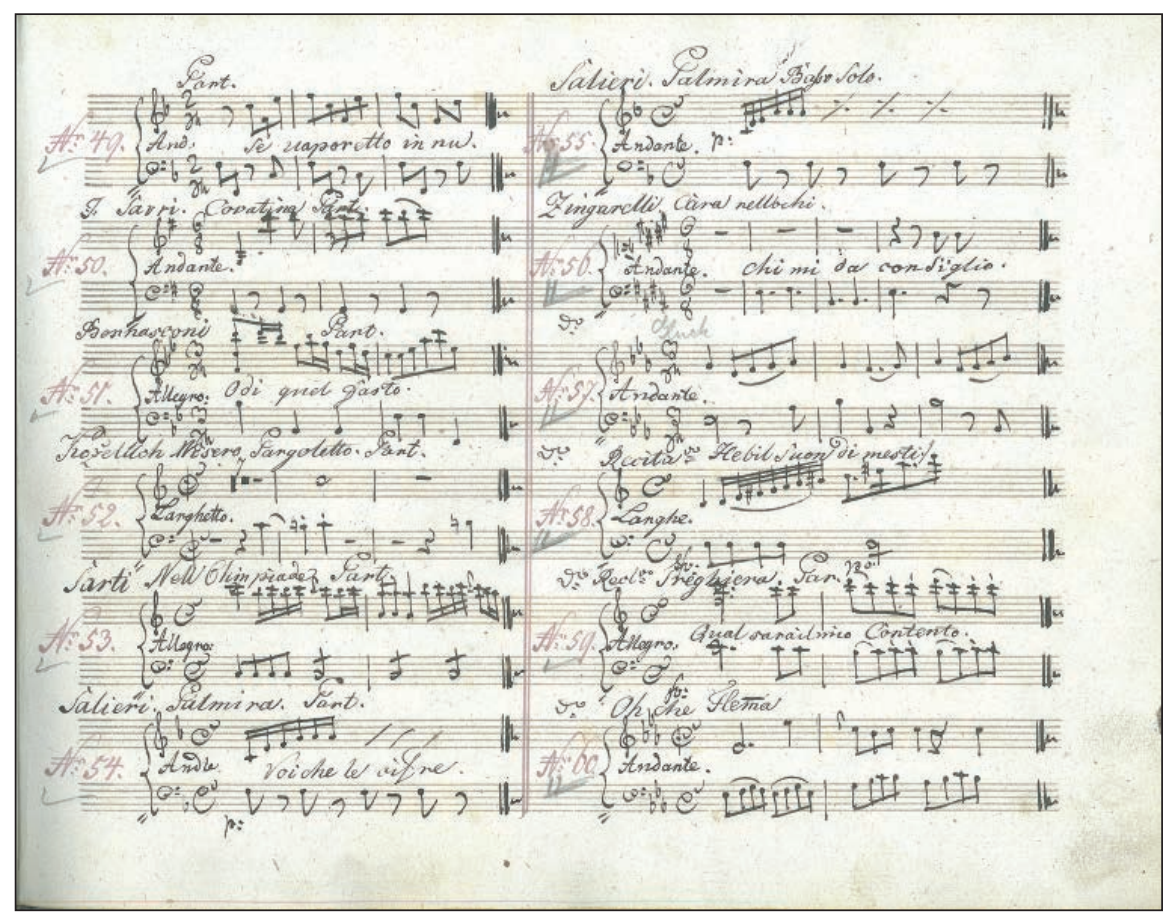

Fig. 4 The record connected to the opera Antigona in the Kačina music inventory (Nr. 49), CZ-Pnm, Kačina, přír. č. 95/65,2 


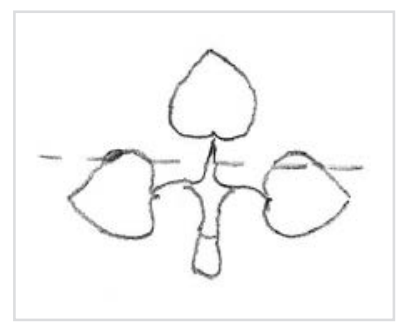

Fig. 5 The watermark in the Breslau score

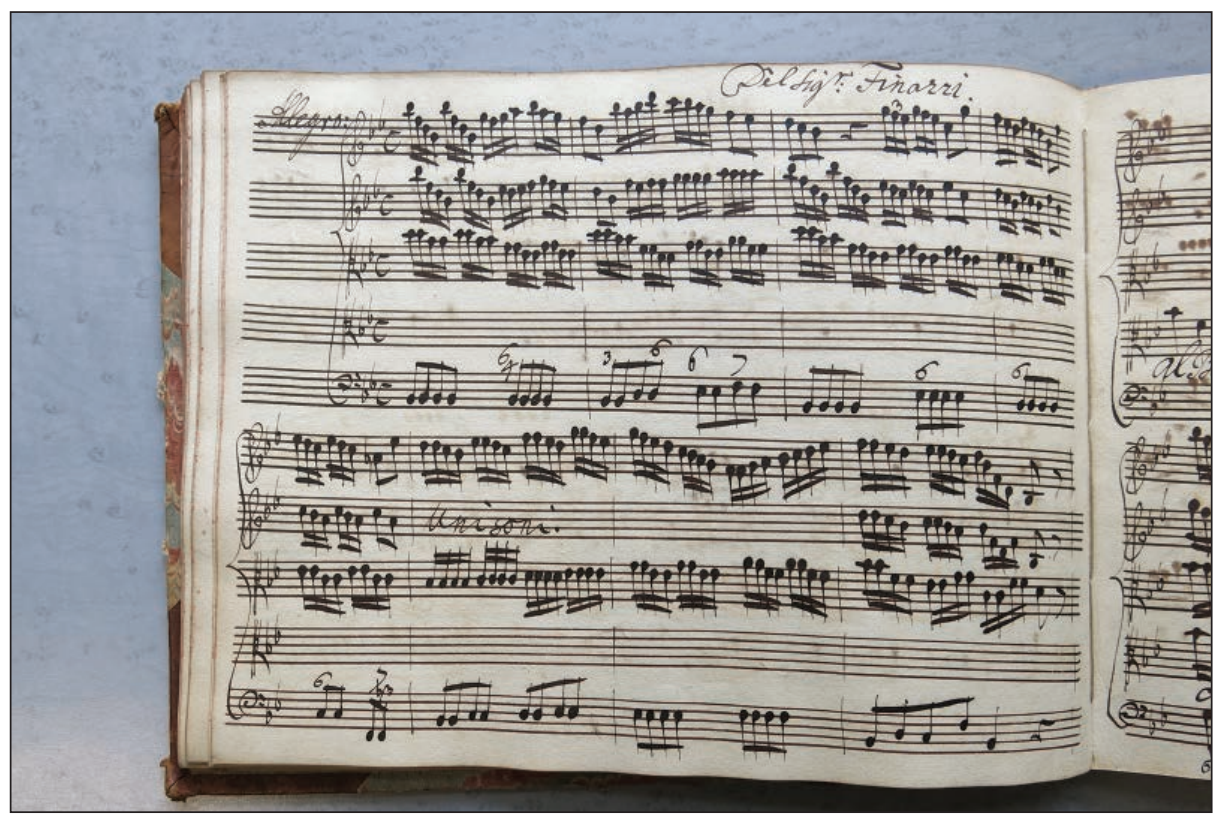

Fig. 6 Indication of Finazzi's authorship in the score 


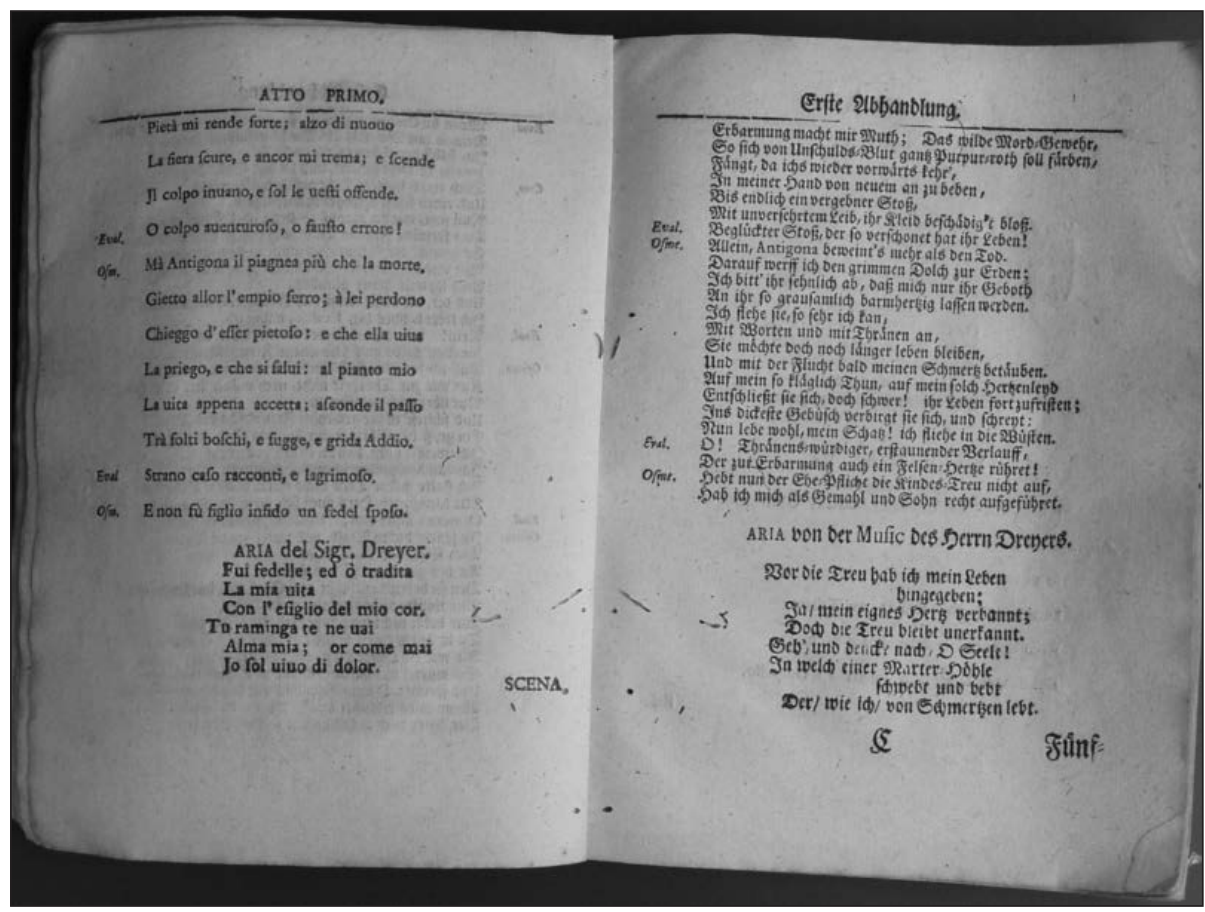

Fig. 7 Indication of Dreyer's authorship in the printed libretto 
Orlandini's Antigona (vendicata): Transformation of a Venetian Opera on its Transalpine Journey

Table 1 Interrelations of the opera repertoire of Central-European opera centres

\begin{tabular}{|c|c|c|c|}
\hline & BRESLAU & PRAG & MORAVIA \\
\hline Alessandro nell'Indie & 1734 (carnival), Bioni & 1734 (autumn), Lucchini & Vyškov 1734, Vinci \\
\hline Alessandro severo & 1733, Bioni & & Brno 1740, Lucchini \\
\hline Antigona vendicata & 1728, Orlandini & & $\begin{array}{l}\text { Brno } 1736 \text { (as Antigona } \\
\text { in Tebe) }\end{array}$ \\
\hline Argippo & & 1730, Vivaldi & $\begin{array}{l}\text { Brno 1733, Costantini } \\
\text { (pasticcio) }\end{array}$ \\
\hline Armida abbandonata & 1726, Bioni & 1725, Bioni & Brno 1733, Bambini \\
\hline Armida al campo & 1726, Bioni & 1728, Guerra & \\
\hline Artaserse & 1733, pasticcio & & $\begin{array}{l}\text { Kroměříž 1731, Hasse; } \\
\text { Holešov 1733, Bambini }\end{array}$ \\
\hline Astarto & 1725, Treu & 1728, Albinoni & $\begin{array}{l}\begin{array}{l}\text { Kroměříž 1730, Bonon- } \\
\text { cini }\end{array} \\
\end{array}$ \\
\hline $\begin{array}{l}\text { La costanza combattu- } \\
\text { ta in amore }\end{array}$ & 1725, Porta & 1728, Porta & \\
\hline II Demetrio & 1732, Bioni (pasticcio) & & Kroměříž 1733, Hasse \\
\hline Didone & 1726, Albinoni & 1731, Albinoni & Brno 1734, Sarro \\
\hline $\begin{array}{l}\text { Don Chisciotte in Sierra } \\
\text { Morena }\end{array}$ & 1727, Treu & & Jaroměřice 1727 \\
\hline Engelberta & $\begin{array}{l}\text { 1729, Bioni (as L'innocen- } \\
\text { za riconosciuta in Engel- } \\
\text { berta) }\end{array}$ & & $\begin{array}{l}\text { Kroměříž } 1728 \text { (as L'En- } \\
\text { gelberta) }\end{array}$ \\
\hline $\begin{array}{l}\text { La fede tradita e ven- } \\
\text { dicata }\end{array}$ & 1729, Bioni & 1727, Gasparini & \\
\hline Filindo & 1728, Bioni & $\begin{array}{l}\text { Regensburg } 1733 \text { (Den- } \\
\text { zio's company) }\end{array}$ & \\
\hline Gli amori amari & & $\begin{array}{l}\text { 1732, Costantini (pastic- } \\
\text { cio) }\end{array}$ & \begin{tabular}{|l|l|}
$\begin{array}{l}\text { Brno 1733, Costantini } \\
\text { (pasticcio) }\end{array}$ \\
\end{tabular} \\
\hline Griselda & $\begin{array}{l}1728 \text { (as La costanza di } \\
\text { Griselda, pasticcio) }\end{array}$ & 1731 & Kroměříž 1730, Gurecký \\
\hline Issipile & 1732, Bioni & 1735, pasticcio & \begin{tabular}{|l} 
Jaroměřice 1733 , Conti; \\
Jaroměřice 1737 Bioni [?]
\end{tabular} \\
\hline Lucio Vero & 1727, Bioni & 1725, Albinoni & $\begin{array}{l}\text { Brno 1734, Galuppi (pas- } \\
\text { ticcio) }\end{array}$ \\
\hline Merope & 1728, pasticcio & 1731 & $\begin{array}{l}\text { Kroměříž } 1727 \text { (pastic- } \\
\text { cio); Jaroměřice 1737, } \\
\text { Broschi }\end{array}$ \\
\hline Orlando furioso & 1725 and 1734 , Bioni & 1724, Bioni & $\begin{array}{l}\text { Brno 1735, Vivaldi (pas- } \\
\text { ticcio) }\end{array}$ \\
\hline La pravita castigata & & 1730 [Caldara] & $\begin{array}{l}\text { Brno 1734, Bambini (pas- } \\
\text { ticcio) }\end{array}$ \\
\hline Siroe & 1732, Bioni & 1734, Vinci & Jaroměřice 1735 , Sarro \\
\hline Teseo in Creta & 1729, pasticcio & & $\begin{array}{l}\text { Brno } 1734 \text { (as Arianna e } \\
\text { Teseo) }\end{array}$ \\
\hline Tullo Ostilio & & 1727 & $\begin{array}{l}\text { Brno 1735, Vivaldi (pas- } \\
\text { ticcio) }\end{array}$ \\
\hline Ulisse e Telemaco & 1726, Treu & & $\begin{array}{l}\text { Brno } 1739 \text { (as Penelope } \\
\text { la casta), Porta }\end{array}$ \\
\hline
\end{tabular}


Table 2 Cast of the Antigona productions between Venice and Central Europe

\begin{tabular}{|l|l|l|l|l|l|}
\hline & $\begin{array}{l}\mathbf{1 7 1 8} \text { Venice, } \\
\text { S. Cassian }\end{array}$ & $\begin{array}{l}\mathbf{1 7 2 1} \text { Venice, } \\
\text { S. Angelo }\end{array}$ & $\begin{array}{l}\mathbf{1 7 2 4} \text { Venice, } \\
\text { S. Cassian }\end{array}$ & 1728 Breslau & 1736 Brno \\
\hline Antigona (A) & Vico, Diana & $\begin{array}{l}\text { Merighi, An- } \\
\text { tonia }\end{array}$ & Lancetti, Lucia & $\begin{array}{l}\text { Orlandi, Chia- } \\
\text { ra (A) }\end{array}$ & Peruzzi, Teresa \\
\hline Creonte (T) & Borghi, Gaetano & $\begin{array}{l}\text { Barbieri, An- } \\
\text { tonio }\end{array}$ & Baratti, Pietro & $\begin{array}{l}\text { Alberti, Giu- } \\
\text { seppe Nicola } \\
\text { (T) }\end{array}$ & $\begin{array}{l}\text { Alberti, Giu- } \\
\text { seppe Nicola }\end{array}$ \\
\hline Osmene (A) & $\begin{array}{l}\text { Urbani, Valen- } \\
\text { tino }\end{array}$ & $\begin{array}{l}\text { Albertini, Giro- } \\
\text { lamo }\end{array}$ & Grimaldi, Nicola & $\begin{array}{l}\text { Dreyer, Gio- } \\
\text { vanni (A) }\end{array}$ & $\begin{array}{l}\text { Moretti, Mar- } \\
\text { garita }\end{array}$ \\
\hline Giocasta (S) & Cavazzi, Antonia & $\begin{array}{l}\text { Strada, Anna } \\
\text { Maria }\end{array}$ & Peruzzi, Teresa & $\begin{array}{l}\text { Bianchi, Bar- } \\
\text { bara (A) }\end{array}$ & $\begin{array}{l}\text { Cosimi, Anna } \\
\text { (S) }\end{array}$ \\
\hline Ceraste (S) & $\begin{array}{l}\text { Baldassari, Be- } \\
\text { nedetto }\end{array}$ & Orlandi, Chiara & Gizzi, Domenico & $\begin{array}{l}\text { Finazzi, Filip- } \\
\text { po (S) }\end{array}$ & $\begin{array}{l}\text { Moretti, Loren- } \\
\text { zo (T) }\end{array}$ \\
\hline Evalco (A) & $\begin{array}{l}\text { Minelli, Giovanni } \\
\text { Battista }\end{array}$ & $\begin{array}{l}\text { Laurenti, Anto- } \\
\text { nia (La Coralli) }\end{array}$ & Pasi, Stefano & $\begin{array}{l}\text { Ferri, Chiara } \\
\text { (A) }\end{array}$ & Galetti, Filippo \\
\hline Ormindo (B) & Claudii, Antonio & $\begin{array}{l}\text { Denzio, Anto- } \\
\text { nio }\end{array}$ & $\begin{array}{l}\text { Pertici, Fran- } \\
\text { cesco }\end{array}$ & $\begin{array}{l}\text { Burigotti, San- } \\
\text { to (S cleff?) }\end{array}$ & $\begin{array}{l}\text { Cajo, Bartolo- } \\
\text { meo (B) }\end{array}$ \\
\hline
\end{tabular}

Table 3 Arias in Venice 1718 (1724) and Breslau 1728 - text

\begin{tabular}{|c|c|c|c|c|c|c|}
\hline \multicolumn{3}{|c|}{ VENICE 1718} & \multirow{2}{*}{\begin{tabular}{|l|}
$\begin{array}{l}\text { Score } \\
\text { US-SFsc }\end{array}$ \\
16
\end{tabular}} & \multicolumn{2}{|c|}{ BRESLAU 1728} & \multirow{2}{*}{\begin{tabular}{|l|}
$\begin{array}{l}\text { Score } \\
\text { CZ-Pnm }\end{array}$ \\
1
\end{tabular}} \\
\hline $\mathrm{I} / 1$ & Ceraste & Se vaporetto in nuvoletto & & $1 / 1$ & & \\
\hline $1 / 2$ & $\begin{array}{l}\text { Creon- } \\
\text { te }\end{array}$ & Fu di re comando allora & 17 & $1 / 2$ & & 2 \\
\hline $1 / 3$ & Ceraste & Ligio sono, e sono amante & 19 & $1 / 3$ & no aria $[=1724]$ & --- \\
\hline $1 / 4$ & $\begin{array}{l}\text { Osme- } \\
\text { ne }\end{array}$ & Fui fedele, ed ho tradita & 29 & $1 / 4$ & & 3 \\
\hline $1 / 5$ & Evalco & Or che al ciel Giocasta è cara & 28 & $1 / 5$ & & 4 \\
\hline $1 / 6$ & $\begin{array}{l}\text { Antigo- } \\
\text { na }\end{array}$ & Poiche il dorso al mar flagella & 5 & $1 / 6$ & $\begin{array}{l}\text { no aria [new text at the } \\
\text { end of the Scene] }\end{array}$ & --- \\
\hline $11 / 2$ & $\begin{array}{l}\text { Antigo- } \\
\text { na }\end{array}$ & Tace il labbro, e parla il ciglio & 30 & $1 / 8$ & & 13 \\
\hline $\mathrm{II} / 3$ & $\begin{array}{l}\text { Giocas- } \\
\text { ta }\end{array}$ & A un balen del ciglio amato & 20 & $1 / 9$ & & 14 \\
\hline $11 / 5$ & $\begin{array}{l}\text { Osme- } \\
\text { ne }\end{array}$ & Al fulgor d'amica stella & 26 & I/11 & & 24 \\
\hline II/6 & $\begin{array}{l}\text { Antigo- } \\
\text { na }\end{array}$ & Stagion novella & 4 & $1 / 12$ & $\begin{array}{l}\text { Poiche il dorso al mar } \\
\text { flagella }[=1 / 6]\end{array}$ & 15 \\
\hline $11 / 7$ & $\begin{array}{l}\text { Creon- } \\
\text { te }\end{array}$ & Sarai sposa: io dono il regno & 13 & $1 / 13$ & & 16 \\
\hline II/8 & Ceraste & Pensa al regno & 9 & I/14 & & 17 \\
\hline $11 / 9$ & $\begin{array}{l}\text { Giocas- } \\
\text { ta }\end{array}$ & Verserò dagli occhi il pianto & 27 & $1 / 15$ & & 18 \\
\hline $\mathrm{III} / 1$ & Evalco & Se a teso lino alato pino & 23 & II/1 & $\begin{array}{l}\text { Dona tempo al gran } \\
\text { consiglio [1724: no aria] }\end{array}$ & 5 \\
\hline $\mathrm{III} / 2$ & $\begin{array}{l}\text { Antigo- } \\
\text { na }\end{array}$ & O sul soglio, o a'vostri altari & 22 & $11 / 2$ & & 6 \\
\hline
\end{tabular}


Orlandini's Antigona (vendicata): Transformation of a Venetian Opera on its Transalpine Journey

\begin{tabular}{|c|c|c|c|c|c|c|}
\hline \multicolumn{3}{|c|}{ VENICE 1718} & \multirow{2}{*}{\begin{tabular}{|l|}
$\begin{array}{l}\text { Score } \\
\text { US-SFsc }\end{array}$ \\
14
\end{tabular}} & \multicolumn{2}{|c|}{ BRESLAU 1728} & \multirow{2}{*}{$\begin{array}{l}\text { Score } \\
\text { CZ-Pnm } \\
10\end{array}$} \\
\hline $111 / 3$ & $\begin{array}{l}\text { Osme- } \\
\text { ne }\end{array}$ & Vanne al padre, e vanne al re & & $11 / 3$ & Al padre vanne e di cosi & \\
\hline $\mathrm{III} / 4$ & $\begin{array}{l}\text { Giocas- } \\
\text { ta }\end{array}$ & Vado sposa, e vado amante & 21 & $\mathrm{II} / 4$ & & 7 \\
\hline $111 / 5$ & $\begin{array}{l}\text { Ormin- } \\
\text { do }\end{array}$ & $\begin{array}{l}\text { Nacqui ai boschi, e son pas- } \\
\text { tore }\end{array}$ & 24 & $11 / 5$ & & 8 \\
\hline $\mathrm{IV} / 2$ & $\begin{array}{l}\text { Antigo- } \\
\text { na }\end{array}$ & Fremi pur, pensa, e consiglia & 8 & II/10 & & 9 \\
\hline $\mathrm{IV} / 3$ & $\begin{array}{l}\text { Creon- } \\
\text { te }\end{array}$ & Pur ch'io salvi e vita, e regno & 25 & $\mathrm{II} / 11$ & & 11 \\
\hline $\mathrm{IV} / 4$ & Ceraste & Per sperar ardo d'amore & 7 & $\mathrm{II} / 12$ & & 19 \\
\hline $\mathrm{IV} / 5$ & $\begin{array}{l}\text { Giocas- } \\
\text { ta }\end{array}$ & Se non mi dici, spera & 10 & III/1 & & 20 \\
\hline IV/6 & Evalco & Fiumicel, che scarsa hà l'onda & 12 & $\mathrm{III} / 2$ & & missing \\
\hline $\mathrm{IV} / 8$ & $\begin{array}{l}\text { Creon- } \\
\text { te }\end{array}$ & Traditori sposi indegni & 18 & $\mathrm{III} / 4$ & & 21 \\
\hline $\mathrm{IV} / 9 \mathrm{a}$ & $\begin{array}{l}\text { Osme- } \\
\text { ne }\end{array}$ & Reo del padre, che salvai & 15 & $111 / 5$ & & 22 \\
\hline IV/9b & $\begin{array}{l}\text { Antigo- } \\
\text { na }\end{array}$ & Odio vuol I'alma sdegnata & 1 & $111 / 6$ & & 23 \\
\hline $\mathrm{V} / 3 \mathrm{a}$ & $\begin{array}{l}\text { Giocas- } \\
\text { ta }\end{array}$ & Tema, amore, il tuo comando & 3 & III/7 & $\begin{array}{l}\text { no aria [end of the } \\
\text { Scene }=1724 \text { ] }\end{array}$ & --- \\
\hline $\mathrm{V} / 3 \mathrm{~b}$ & $\begin{array}{l}\text { Ormin- } \\
\text { do }\end{array}$ & Se a languir quel debil core & 6 & & no aria $[=1724]$ & --- \\
\hline $\mathrm{V} / 4$ & $\begin{array}{l}\text { Creon- } \\
\text { te }\end{array}$ & Stelle oscure non v'intendo & 2 & $\begin{array}{l}\text { III } / 8, \\
\text { Ceraste }\end{array}$ & $\begin{array}{l}\text { Del mio amor l'auree } \\
\text { catene }[=1724, \mathrm{~V} / 2]\end{array}$ & 12 \\
\hline
\end{tabular}

Table 4 Arias in Venice 1718 and Breslau 1728 - music

\begin{tabular}{|l|l|l|l|l|l|l|l|}
\hline $\begin{array}{l}\text { Act/ } \\
\text { Scene }\end{array}$ & Role & $\begin{array}{l}\text { Folios in } \\
\text { score }\end{array}$ & $\begin{array}{l}\text { Aria (according to } \\
\text { libretto) }\end{array}$ & $\begin{array}{l}\text { Key } \\
\mathbf{1 7 1 8} \\
\mathbf{1 7 2 8}\end{array}$ & $\begin{array}{l}\text { Voice } \\
\text { (cleff) } \\
\mathbf{1 7 1 8} \rightarrow \\
\mathbf{1 7 2 8}\end{array}$ & $\begin{array}{l}\text { Music (accor- } \\
\text { ding to score) }\end{array}$ & Author \\
\hline $\mathrm{I} / 1$ & Ceraste & $1 \mathrm{v}-4 \mathrm{r}$ & $\begin{array}{l}\text { Se vaporetto in } \\
\text { nuvoletto }\end{array}$ & $\mathrm{F}$ & soprano & original & \\
\hline $\mathrm{I} / 2$ & Creonte & $4 \mathrm{v}-7 \mathrm{v}$ & $\begin{array}{l}\text { Fu di Re comando } \\
\text { all'ora }\end{array}$ & $\mathrm{B}$ & tenor & original & \\
\hline $\mathrm{I} / 4$ & Osmene & $8 \mathrm{r}-11 \mathrm{r}$ & $\begin{array}{l}\text { Fui fedele, ed o tra- } \\
\text { dita }\end{array}$ & $\mathrm{C} \rightarrow \mathrm{c}$ & alto $\rightarrow$ alto & substituted & Dreyer (lib) \\
\hline $\mathrm{I} / 5$ & Evalco & $11 \mathrm{v}-15 \mathrm{r}$ & $\begin{array}{l}\text { Or che al ciel Gio- } \\
\text { casta e cara }\end{array}$ & $\mathrm{F} \rightarrow \mathrm{F}$ & alto $\rightarrow$ alto & substituted & Dreyer (lib) \\
\hline $\mathrm{I} / 8$ & Antigona & $38 \mathrm{v}-41 \mathrm{r}$ & $\begin{array}{l}\text { Tace il labro, e } \\
\text { parla il ciglio }\end{array}$ & $\mathrm{G}$ & alto & original & \\
\hline $\mathrm{I} / 9$ & Giocasta & $41 \mathrm{v}-44 \mathrm{r}$ & $\begin{array}{l}\text { A un balen del } \\
\text { ciglio amato }\end{array}$ & $\mathrm{A} \rightarrow \mathrm{B}$ & $\begin{array}{l}\text { soprano } \rightarrow \\
\text { alto }\end{array}$ & substituted & $\begin{array}{l}\text { Finazzi (sco- } \\
\text { re) }\end{array}$ \\
\hline $\mathrm{I} / 11$ & Osmene & $71 \mathrm{r}-75 \mathrm{v}$ & $\begin{array}{l}\text { Al fulgor d'amica } \\
\text { stella }\end{array}$ & $\mathrm{D} \rightarrow \mathrm{D}$ & alto $\rightarrow$ alto & substituted & $\begin{array}{l}\text { Dreyer (lib, } \\
\text { score) }\end{array}$ \\
\hline
\end{tabular}


Orlandini's Antigona (vendicata): Transformation of a Venetian Opera on its Transalpine Journey

\begin{tabular}{|c|c|c|c|c|c|c|c|}
\hline $\mathrm{I} / 12$ & Antigona & $44 v-48 v$ & \begin{tabular}{|l|} 
Poiche il dorso al \\
mar flagella
\end{tabular} & $F$ & alto & original & \\
\hline $1 / 13$ & Creonte & $49 r-51 v$ & $\begin{array}{l}\text { Sarai sposa! io } \\
\text { dono il regno }\end{array}$ & $A$ & tenor & original & \\
\hline $\mathrm{I} / 14$ & Ceraste & $52 r-55 r$ & $\begin{array}{l}\text { Pensa al regno, e } \\
\text { a chi lo dona }\end{array}$ & $B$ & soprano & original & \\
\hline $\mathrm{I} / 15$ & Giocasta & $55 v-57 v$ & $\begin{array}{l}\text { Versero dagli occhi } \\
\text { il pianto }\end{array}$ & $D \rightarrow A$ & $\begin{array}{l}\text { soprano } \rightarrow \\
\text { alto }\end{array}$ & $\begin{array}{l}\text { transposed } \\
\text { (fourth down) }\end{array}$ & \\
\hline $\mathrm{II} / 1$ & Evalco & $15 v-17 v$ & $\begin{array}{l}\text { Dona tempo al } \\
\text { gran consiglio }\end{array}$ & $\rightarrow G$ & $\rightarrow$ alto & new & Dreyer (lib) \\
\hline $\mathrm{II} / 2$ & Antigona & $18 r-19 v$ & $\begin{array}{l}\text { O sul soglio, } \\
\text { o a vostri altari }\end{array}$ & $D$ & alto & original & \\
\hline $11 / 3$ & Osmene & $28 r-31 r$ & $\begin{array}{l}\text { Al padre vanne e } \\
\text { di cosi }\end{array}$ & $g \rightarrow g$ & alto $\rightarrow$ alto & $\begin{array}{l}\text { substituted, } \\
\text { new text }\end{array}$ & Dreyer (lib) \\
\hline $\mathrm{II} / 4$ & Giocasta & $19 v-22 v$ & $\begin{array}{l}\text { Vado sposa, e } \\
\text { vado amante }\end{array}$ & $A \rightarrow E$ & $\begin{array}{l}\text { soprano } \rightarrow \\
\text { alto }\end{array}$ & $\begin{array}{l}\text { transposed } \\
\text { (fourth down) }\end{array}$ & \\
\hline $11 / 5$ & Ormindo & $23 r-25 r$ & $\begin{array}{l}\text { Naqui ai boschi, e } \\
\text { son pastore }\end{array}$ & $E s \rightarrow F$ & $\begin{array}{l}\text { bass } \rightarrow \\
\text { soprano }\end{array}$ & substituted & $?$ \\
\hline II/10 & Antigona & $25 v-27 v$ & $\begin{array}{l}\text { Fremi pur, pensa, e } \\
\text { consiglia }\end{array}$ & $G \rightarrow F$ & alto $\rightarrow$ alto & $\begin{array}{l}\text { transposed (se- } \\
\text { cond down) }\end{array}$ & \\
\hline II/11 & Creonte & $31 v-34 v$ & $\begin{array}{l}\text { Pur ch'io salvi e } \\
\text { vita, e regno }\end{array}$ & $c \rightarrow E s$ & $\begin{array}{l}\text { tenor } \rightarrow \\
\text { bass }\end{array}$ & substituted & $?$ \\
\hline II/12 & Ceraste & $58 r-60 v$ & $\begin{array}{l}\text { Per sperar ardo } \\
\text { d'amore }\end{array}$ & $B \rightarrow F$ & $\begin{array}{l}\text { soprano } \rightarrow \\
\text { soprano }\end{array}$ & substituted & $?$ \\
\hline $\mathrm{III} / 1$ & Giocasta & $61 r-63 r$ & $\begin{array}{l}\text { Se non mi dici, } \\
\text { spera }\end{array}$ & $C \rightarrow F$ & \begin{tabular}{|l|} 
soprano $\rightarrow$ \\
alto
\end{tabular} & \begin{tabular}{|l|} 
transposed \\
(fifth down)
\end{tabular} & \\
\hline $\mathrm{III} / 2$ & Evalco & & $\begin{array}{l}\text { Fiumicel, che scar- } \\
\text { sa ha l'onda }\end{array}$ & & & missing & \\
\hline $\mathrm{III} / 4$ & Creonte & $63 v-65 v$ & $\begin{array}{l}\text { Traditori, sposi } \\
\text { indegni }\end{array}$ & $D$ & tenor & original & \\
\hline $111 / 5$ & Osmene & $66 r-68 r$ & $\begin{array}{l}\text { Reo del padre che } \\
\text { salvai }\end{array}$ & $F$ & alto & original & \\
\hline $111 / 6$ & Antigona & $68 v-70 v$ & $\begin{array}{l}\text { Odio vuol l'alma } \\
\text { sdegnata }\end{array}$ & $A \rightarrow G$ & alto $\rightarrow$ alto & $\begin{array}{l}\text { transposed (se- } \\
\text { cond down) }\end{array}$ & \\
\hline III/8 & Ceraste & $35 r-37 v$ & $\begin{array}{l}\text { Del mio amor } \\
\text { l'auree catene }\end{array}$ & $\rightarrow F$ & $\rightarrow$ soprano & new [1724?] & ? \\
\hline
\end{tabular}

\section{Bibliography}

BORCHERDT, Hans Heinrich. Geschichte der italienischen Oper in Breslau. Zeitschrift des Vereins für Geschichte Schlesiens, 1910, vol. 44, pp. 18-51.

ČERNÁ, Zuzana. Antonio Bioni and His Compositions Preserved in Kroměříž Archive, Musicologica Brunensia, 2017, vol. 52, no. 2, pp. 217-242.

FREEMAN, Daniel E. The Opera Theater of Count Franz Anton von Sporck in Prague. Studies in Czech Music 2, Stuyvesant - New York: Pendragon Press, 1992.

FUKAČ, Jiří. Dochované inventáře chotkovské hudební sbírky na zámku Kačina. Jiří K. Kroupa and Jana Spáčilová (eds.). Antiqua Cuthna 5-11, Praha 2015, s. 42-64.

HAVLÍČKOVÁ, Margita. Berufstheater in Brünn 1668-1733. Brno: MU, 2012. 
JONÁŠOVÁ, Milada. I Denzio: tre generazioni di musicisti a Venezia e a Praga. Hudební věda, 2008, vol. 45, no. 1-2, pp. 57-114.

MACEK, Ondřej. Vivaldi's Prague Opera Argippo and its Reconstruction, In MACEK, Petr - PERUTKOVÁ, Jana (edd.). The Eighteenth-Century Italian Opera Seria. Metamorphoses of the Opera in the Imperial Age. Praha: KLP, 2013, pp. 89-98.

PERUTKOVÁ, Jana. Der glorreiche Nahmen Adami. Johann Adam Graf von Questenberg (1678-1752) als Förderer der italienischen Oper in Mähren. Wien: Hollitzer, 2015.

PERUTKOVÁ, Jana. František Antonín Míca ve službách hraběte Questenberga a italská opera v Jaroměricich [František Antonín Míča in the Services of Count Questenberg and Italian Opera in Jaroměřice]. Praha: KLP, 2011.

QUANTZ, Johann Joachim. Herrn Johann Joachim Quantzens Lebenslauf, von ihm selbst entworfen. In MARPURG, Friedrich Wilhelm (ed.). Historisch-Kritische Beyträge zur Aufnahme der Musik, Bd. 1, St. 3, Berlin 1755, pp. 197-250.

SARTORI, Claudio. I libretti italiani a stampa dalle origini al 1800. Catalogo analitico con 16 indici. Cuneo: Bertola e Locatelli, 1990-1994.

SEHNAL, Jiří. Hudebni literatura zámecké knihovny v Kroměrižzi [Music Literature in the Castle Library in Kroměříž], Gottwaldov: Oblastní museum a galerie, 1960.

SEHNAL, Jiří. Počátky opery na Moravě. Současný stav vědomostí [The Origins of the Opera in Moravia: The Current State of Knowledges]. In PETRŮ, Eduard (ed.). O divadle na Moravě. AUPO, Facultas philosophica, Supplementum 21. Praha: SPN, 1974, pp. 55-77.

SELFRIDGE-FIELD, Eleanor. A New Chronology of Venetian Opera and Related Genres, 1660-1760, Stanford: Stanford University Press, 2007.

SCHIERSE, Bruno Bernhard. Das Breslauer Zeitungswesen vor 1742. Breslau: J. U. Kern, 1902.

SOMMER-MATHIS, Andrea. Die Anfänge des Wiener Kärntnertortheaters zwischen deutschprächiger Stegreifkomödie und italienischer Oper. Divadelni revue, 2015, vol. 26, pp. 139-152.

SPÁČILOVÁ, Jana. Die Rezeption der italienischen Oper am Hofe des Olmützer Bischofs Schrattenbach. In MACEK, Petr - PERUTKOVÁ, Jana (edd.). The Eighteenth-Century Italian Opera Seria. Metamorphoses of the Opera in the Imperial Age. Praha: KLP, 2013, pp. 75-88.

SPÁČILOVÁ, Jana. Soloists of the Opera Productions in Brno, Holešov, Kroměříž and Vyškov. Italian Opera Singers in Moravian Sources c. 1720-1740 (Part I). In ZUR NIEDEN, Gesa - OVER, Berthold (edd.). Musicians' Mobilities and Music Migrations in Early Modern Europe. Biographical Patterns and Cultural Exchanges, Mainz: Transcript-Verlag, 2016, pp. 255-273.

SPÁČILOVÁ, Jana. Počátky opery ve Slezsku - současný stav pramenů [The Origins of the Opera in Silesia - the Current State of Sources]. Musicologica Brunensia, 2016, vol. 51, no. 2, pp. $157-170$.

SPÁČILOVÁ, Jana. Catalogue of the Italian Opera Libretti in Central Europe in the 1st Half of the 18th Century, I: Moravia. Clavis monumentorum musicorum regni Bohemiae, series S, VIII. Praha: KLP, in preparation.

STROHM, Reinhard. Essays on Handel and Italian Opera. Cambridge: Cambridge University Press, 1985.

ŠKERLJ, Stanko. Italijansko gledališče v Ljubljani v preteklih stoletjih. Il teatro italiano a Ljubljana nei secoli passati. Ljubljana: SAZU, 1973.

Verzeichnis aller welschen Opern, welche von 1725 bis 1734 auf dem breslauischen Schauplatz vorgestellet worden sind. In MATTHESON, Johann. Grundlage einer Ehrenpforte, Hamburg, 1740 , pp. $374-378$. 